\title{
Strategies for Teaching the Articles - a, an, the
}

\author{
Amelia Leong Chiew Har \\ (Universiti Putra Malaysia, Malaysia) \\ doi:10.7575/aiac.alls.v.2n.2p.129
}

\begin{abstract}
It is undeniable that learning the articles $a$, $a$, and the presents serious difficulties to the learners and teachers alike in the English Language classrooms, but previous studies done on the teaching of articles have shown that there are many techniques of teaching the articles that can be employed in the English Language classrooms. Besides the techniques suggested by the linguists and researchers, the paper also presents strategies on teaching the articles from various sources like grammar books and research journals in the area. Examples of the teaching strategies are given in relation to the strategies suggested.
\end{abstract}

\section{Introduction}

The English grammar articles $-a$, an and the is categorized as the determiners in the English grammar. The English articles system is one of the most commonly used aspects of grammar in the English Language. According to Thornbury (2004, p.8), the articles $a$ and the are the two out of the ten most frequent words in the English Language. The articles system is used widely and frequently; intentionally or unintentionally in all the four skills - speaking, listening, writing and reading. It plays a crucial role in learning the language as it helps to achieve accuracy and fluency in English language and to achieve communication skills.

However, the English grammar articles system is "one of the most difficult grammatical items for the non-native English speakers to learn" (Yamada \& Matsuura, 1982, p.50) and it is "one of the latest to be fully acquired as English articles system is said to be complex" (Master, 1990, p.461). Hence, it is important to teach the usage of the articles to the learners.

In Malaysia, the Ministry of Education (MOE) has listed all the three articles $-a$, an, the in the Form 1 to Form 5 English Language Kurikulum Bersepadu Sekolah Menengah (KBSM) syllabus. This shows that all the three articles will be taught to the learners from Form 1 to 
Form 5 English Language classrooms. Table 1 shows the list of articles listed in the Malaysian Secondary School English Language syllabus.

\section{Table 1: Curriculum specification for English language (articles) in Forms 1-5}

\begin{tabular}{cc}
\hline Form 1 & A, An, The, Zero Article \\
Form 2 & A, An, The, Zero Article \\
Form 3 & A, An, The, Zero Article \\
Form 4 & A, An, The, Zero Article \\
Form 5 & A, An, The, Zero Article \\
\hline \multicolumn{2}{l}{ Source: Curriculum Specification for English Language (MOE, 2003) }
\end{tabular}

Hence, the articles are expected to be taught to the learners in the English Language classrooms. In Malaysia, the articles are taught to the learners mainly by using the English Language textbooks provided by the Textbook Bureau of the Malaysia's Ministry of Education.

Thornbury (2004, p.41) in How To Teach Grammar shows us how the articles can be possibly taught in the English language classrooms using the deductive approach by involving the learners in the jigsaw activities and group work, utilizing the cloze texts. It is believed that jigsaw activity and group work help to provide more opportunities to the learners to be involved in the real-world communication and training the learners to be more responsible to their own learning. Thornbury (2004, p.43) also reported that this approach of teaching articles is economical as teaching articles can be easily done by directing the learners to the rules of grammar in the handouts prepared by the teachers or referring the learners to the grammar sections of a reference book. Teaching the grammar articles solely by the teachers is not an easy attempt, hence employing this approach helps to ease the teachers' burden in the teaching and learning process. It is "likely to have a more enduring effect on memory than simply reading the rules and doing the exercise" (Thornbury, 2004, p.43).

\section{Teaching grammar}

Previous studies on the teaching of grammar have shown that there have been debates on the process of teaching and learning the English grammar. Some argue that grammar should not be taught but it must be acquired by the learners through their daily communication and use of the English Language (Webbe, 1622 in Thornburry, 2004, p.19). This approach is called 
Inductive Approach and is supported by the Communicative Language Teaching (Richards and Rogers, 1986). The proponents of this approach contend that grammar can be acquired (picked up) by the learners naturally without studying the rules of grammar. Hence, the inductive approach supports the Direct Method and Audiolingualism as the grammar teaching and learning methodology in the English Language classrooms. The Direct Method claimed to be supporting the Natural Approach by Krashen (1974) while the Audiolingualism strictly rejected the idea of grammar teaching, based on the idea of behaviorism (Skinner, 1974).

On the other hand, others have argued that in order to learn grammar effectively, one has to first study the rules of the grammar (deductive approach). There is a need for the learning of the rules to take place first as the learning of rules enables the production of new sentences in the language. Reportedly the teaching and learning of the grammar rules can prevent fossilization of errors to take place in Second Language Learning (Selinker, 1972) as learners are aware of the grammar rules and prevent them from using the grammar inaccurately. This deductive approach in the learning of grammar leads to the emergence of a grammar teaching method that can be applied and employed in the teaching of the grammar in the English Language classrooms. The teaching method that puts forward the teaching of the rules of grammar is the Grammar-Translation Method which teaches the rules of grammar in the beginning of the lessons and grammar is taught explicitly rather than implicitly in the English Language classrooms.

Therefore, both approaches have advantages and disadvantages. Whether one should teach grammar inductively or deductively highly depends on the learning-teaching context. It depends highly on the teachers, the learners and the grammar teaching methods used by the teachers to make the teaching and learning of grammar effective (Thornbury, 2004).

\section{The teaching of articles}

Previous studies done on the English grammar articles have highlighted several teaching techniques and approaches that can be employed in the teaching of the articles $a$, an and the. As the learning and acquisition of the English grammar articles has always posed problems to the learners; hence, linguists have came out with several teaching techniques and approaches in teaching the articles so that the teaching and learning process of the articles will be more effective. 
Whitman (1974, p.253) has suggested six consecutive steps for teaching the articles as he assumed that the article structure "is a sequence of quantification and determination rather than a choice between specified and unspecified". The six steps suggested are as follows:

1. Quantity (singular/plural distinction)

- $\quad$ eg. John has a book vs. John has four books.

2. Generic plural

- $\quad$ eg. All apples are red vs. Apples are red.

3. Non-count nouns (Non-count vs. count and a lot of vs. much and many)

- $\quad$ eg. John drank a lot of water vs. John bought a lot of books.

- $\quad$ eg. Do we have much water? vs. Do we have many books?

4. Determiners (which -NP questions and first /subsequent mention)

- $\quad$ eg. Which books are red? The red books are on the table.

- $\quad$ eg. I read a book. The book was called Dracula.

5. Quantity and determiner

- $\quad$ eg. One of the books on the table is blue.

6. Generic articles

- $\quad$ eg. Elephants never forget.

- $\quad$ eg. An elephant never forgets.

- $\quad$ eg. The elephant never forgets.

(Examples are taken from Whitman, 1974, p.253)

Whitman arranged quantity to be the first step among the six as he felt that "the concept of 'counting' is easier to talk about than the concept of "known groups"' (Whitman, 1974, p.258). He placed the generic article $a$ and the the last among the six as the generic $a$ and the are the least found.

On the other hand, Grannis (1972) has posited that the best way for the learners to learn the English grammar articles and for the teachers to teach the articles is to employ the traditional approach. Grannis (1972) opposed to the ideas of teaching the articles based on the theory or concept in explaining the use of the articles as the formal instructions. He (ibid.) also reports that the theory in the grammar books might lack the real ideas and information on the usage of the articles. Thus, he urged the teachers to "fall back into a basically unstructured, traditional approach to the description of English" (Grannis, 1972, p.288).

On the contrary, Lindstromberg (1986), Berry (1991) and Master (1997) have argued that formal instruction of articles is needed and contributes to the effectiveness in the learning process. They (ibid.) believe that the formal instruction is needed to aid the non-native learners to acquire the positive results in the learning of the articles. Lindstromberg (1986) posits that the formal instruction of articles helps to explain and simplify the complex system of the English grammar articles. 
Although Berry (1991) supported the use of formal instruction and the learning of grammar rules in the teaching and learning of the English grammar articles, he found out that what were written in the grammar books with regards to the articles were "not yet well in the matter of teaching articles" (p. 255). Berry (1991) reported that there are weaknesses in the grammar books on the explanations on the articles as there are incorrect or misleading information on the articles $a$, an, the, unwarranted emphasis on certain types of article usage and a lack of variety in the techniques of teaching the articles. According to Berry (1991), these weaknesses are severe and can lead to the learners' misconception on the use of the articles. Based on these three weaknesses, Berry (1991, p.256) has come up with seven principles in designing activities for the teaching and learning of articles,

1. Use a principled descriptive account as a basis;

2. Concentrate on the, particularly its specific uses;

3. Emphasize, wherever possible, the value of articles, using contrastive information if appropriate;

4. Make exercises/activities varied and interesting; involve and challenge the learner; use different formats and different stimuli, for example sound, pictures; include open-ended exercises which allow learners to discover the bounds of usage;

5. Do not rely on rules; use them as a back-up to other activities and make sure the formulations are simple but accurate;

6. Grade the focus on particular aspects, but do not try to control the introduction of uses; articles are far too numerous for this;

7. Have exercises which, in addition to production, involve comprehension and perception (e.g. a text with gaps for articles which learners fill in according to a passage they hear)

Similar with Berry's (1991) approach in teaching articles is McEldowney's (1977) four stages of teaching approach,

Stage 1: Classification

$a+\mathrm{N}$ (any one) vs. the $+\mathrm{N}$ (the special one)

Choose a bag vs. Take a red bag.

$\mathrm{N}+\mathrm{s}$ (plural classification)

These are bags.

Stage 2 : Plurality

some $+\mathrm{N}+\mathrm{s}$ (any ones)

Choose some bags from the collection.

the $+\mathrm{N}+s$ (the special ones)

Take the red bags.

Stage 3 : Mass or substance

$\mathrm{N}$ (the substance in general)

Mud is found at the bottom of rivers.

Some + N (any substance)

Some mud is grey; some mud is black.

the $+\mathrm{N}$ (the special substance)

Point to the black mud.

Stage 4 : Numbered specific; generic numeral $\mathrm{N}+\mathrm{s}$ (any numbered ones)

Choose six pens from the collection. 


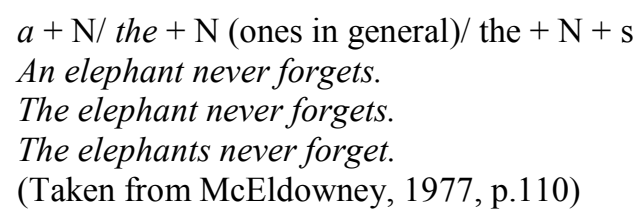

McEldowney (1977) suggested the four-stage teaching approach based on her experience as an English as a Foreign Language (EFL) teachers' trainer and her study on the 'common errors' tradition of French. She suggested the three code markers, in her effort to simplify the English grammar articles which are (1) choice marked by $a$ in the sense of any; (2) specification coded through special the; and (3) generalization through general $-s$ and $a$ and the. The four-stage teaching approach is basically formed based on these three code markers by McEldowney (1991) herself.

From all the previous studies that have been mentioned, all of the suggestions by the practitioners are on developing a simplified framework for the teaching of the articles to the learners. There are a lot of emphases on the ways the teaching of articles can be made simple as to provide clearer explanations and input on their and to better help the learners to achieve mastery in the learning of the article usage.

\section{Teaching strategies on articles}

As English grammar articles pose great difficulties for both the teachers and learners of English as a Second/Foreign Language (ESL/EFL), this paper suggests a few teaching strategies for teaching them, aiming to help both teachers and learners to teach and learn the English grammar articles effectively and to achieve a successful teaching and learning process of the articles in the classrooms. The following teaching strategies suggested are adapted from the English grammar articles' exercises and notes from various grammar books and journals on the teaching of English grammar articles.

First and foremost, teachers are encouraged to tap on the concept of noun countability before start to teach the English grammar articles to the ESL/EFL learners. It is crucial to educate the learners on the distinction between count nouns and non-count nouns in order to help the learners to distinguish between count nouns and non-count nouns. According to Celce-Murcia and Larsen-Freeman (1999, p.273), the "lexical classification of English common nouns into count and non-count nouns is a very important preliminary to correct use of articles". Thus, the correct use of the articles depends highly on the learners' knowledge of count and non- 
count nouns. Celce-Murcia and Larsen-Freeman (1999, p.290) have also suggested on teaching the count and non-count nouns prior to the teaching of the articles to the learners. Hence, teachers should provide exercises and activities on count and non-count nouns to the learners as to provide the opportunities to the learners "to practice the difference between count and non-count nouns" (Celce-Murcia and Larsen-Freeman, 1999, p.290). This can be done by creating exercise/activity with table or grid with two columns separating the count noun from the non-count nouns and ask the learners to sort the given nouns into the appropriate columns whether the noun should be in the count noun column of the non-count noun column. For example,

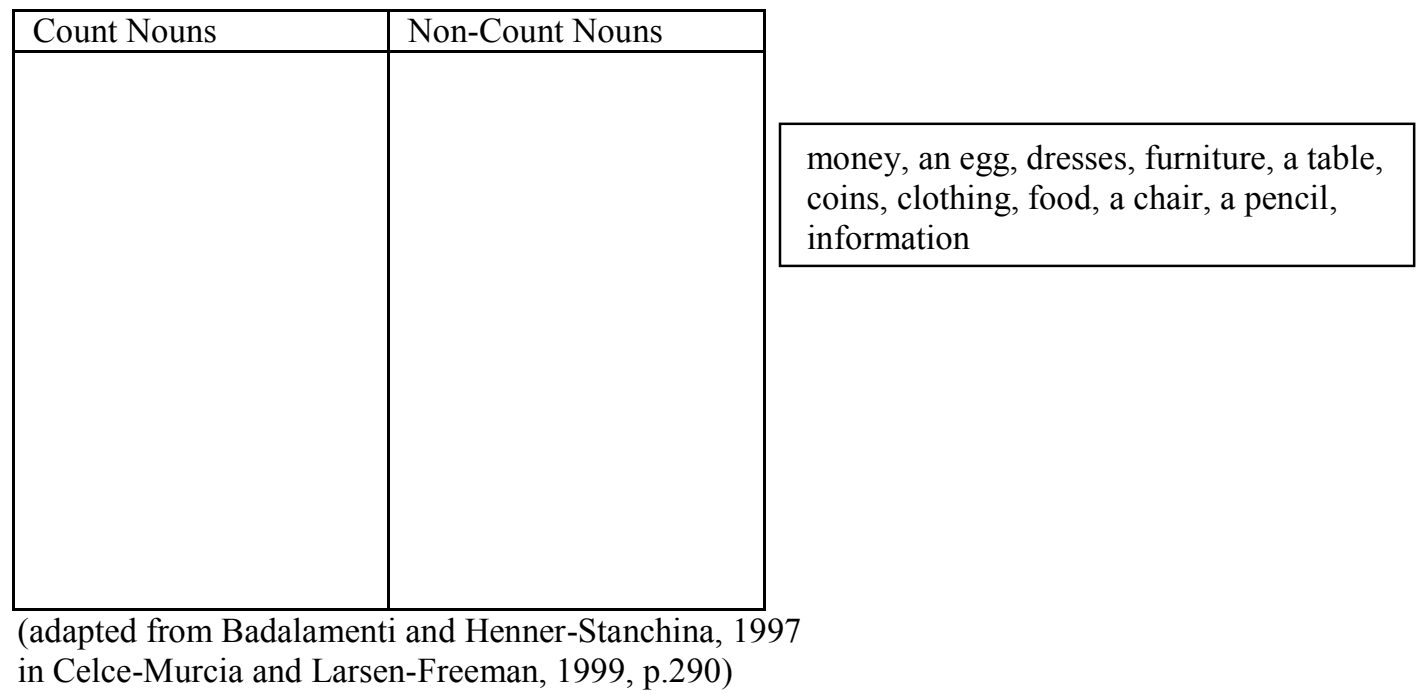

It is believed that this type of activity aids the learners to gain a clearer idea on the distinction of count noun and non-count noun that will helps the learners in using the accurate article with the noun.

Next, when the learners are equipped with the appropriate and sufficient knowledge on count and non-count nouns, then, it would be the right time for the teachers to introduce the articles to the learners. Teachers can introduce the articles based on the definiteness of the articles the definite article and the indefinite articles. In line with what suggested by other linguists such as Whitman (1974) and Berry (1991), the teaching of articles have to be done 1 step at one time, therefore, it would be best that teachers start teaching on the indefinite articles (a,an) first and followed by the indefinite article (the). Exercises that can be given to the learners to work on the indefinite and definite articles would be fill in the blanks where learners are ask to fill in the blanks in the sentences given with the appropriate article. For instance, 
$\underline{\text { Indefinite article }}$

This is_ pen. (a/an)
This is_ eraser. (a/an)
This is bird. (a/an)
This is eagle. (a/an)
(adapted from Celce-Murcia \& Larsen-Freeman, 1999, p.290)

This exercise is aimed to provide the opportunity to the learners to be able to identify and use the appropriate indefinite article with the noun given.

As for definite article, the exercise would be similar to the exercise for the indefinite article but more information would be given to aid the learners to identify the use of the definite article.

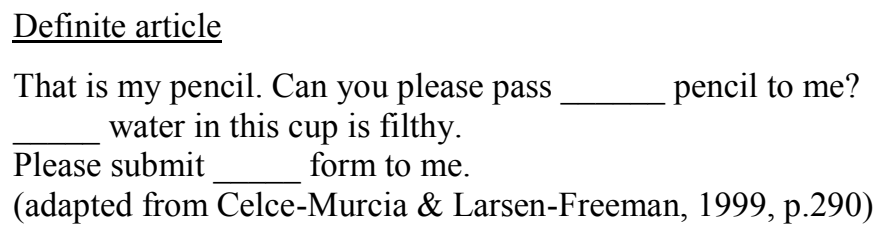

The above exercise on the definite article above highlighted on the use of definite article the with the nouns that are mention for the second time and with the non-count noun.

Once the learners have the knowledge on the use of the definite and indefinite articles, teachers can slowly introduce the exercises that are of higher cognitive level, for instance, the cloze text. The cloze text is the most used exercise / activity in the teaching of articles and most of the time serves as the grammar drills in the teaching of articles as cloze text is "a powerful and economical measure" of ESL proficiency (Stubbs and Tucker, 1974, p.241). A cloze text which is well constructed is capable to test language skills, and even the mastery of grammatical items ranging from the most basic to the most advanced (Gan, 2001, p.2) Hence, cloze text is also used for testing purposes. An example of an easier cloze test is as follows:

Instruction: Listen as your teacher reads the following passage, fill in the articles you hear the teacher say.

Before going out of town, I asked couple of days. He agreed. When friend to keep my car in his garage for accident occurred in which emergency arose, he used my car and responsible for car suffered damages. Is damages? Yes. Without clear permission to use he has no right to use it for his personal benefit. (taken from Rinnert and Hansen, 1986, p.17)

The cloze text above is the most basic and the easiest cloze test as learners do not have to decide for themselves on which articles that they should use but fill in the blanks in the cloze test with the articles that their teachers dictate in the lesson. 
Apart from this cloze test, there are also some other cloze texts which are more difficult and advanced that cater for the advanced learners. Using the most basic cloze text to the more advanced cloze text is also a good way to evaluate the learners' progress in the learning and mastery of the use of the articles.

Instruction : Fill in the blanks with $a$, an or the.

During ___ Watergate scandal of ___ early seventies, everyone from Joseph Alsop to President Gerald Ford was pleading that country should forget about Watergate so President could devote his time and efforts to such important matters as energy crisis. Dr Siegfreed, psychiatrist who wrote book, 'How much can Americans Take?', supports

opposite view. He says it would have been more advantageous if ___ country could forget about energy crisis so President could devote his full time to Watergate. truth is, he claims, that everyone in country got fiendish delight in reading about Watergate, while very few people got any fun out of reading about oil crisis. Watergate was pure entertainment. It had comedy, mystery and melodrama. He would have preferred that it have little sex as well, but he realizes that you can't have everything. identified with ___ Watergate characters. Without Watergate you would have had people mental depression in this country. "Show me anyone who enjoys reading about Produce one soul who gets pleasure put of seeing long lines of energy crisis. cars at gas

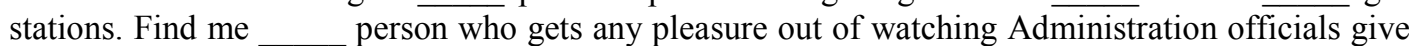
daily conflicting stories on

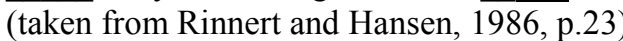
oil situation in country."

The cloze text given above is one of the cloze texts used in the teaching of articles in the ESL classrooms. This type of cloze text caters best for the advanced learners or for the learners who have excellent mastery on the article usage.

If learners are capable and face no difficulties in completing the above cloze text, then, teachers can proceed to a higher level of the teaching of articles which will involve a grammar-checking activity where learners are required to act as the teacher to line out the missing articles that are supposed to be in the passage given. All the articles are omitted on purpose for this activity.

Instruction : Rewrite the passage below using $a$, an and the where appropriate.

Today, our class visited home for disabled children. Some of children were in wheelchairs. Some couldn't talk or walk properly. People who took care of children were patient and gentle.

We had party with people there. We also put up show for them. It was enjoyable day for both children and us.

(taken from Malaysia's Form 3 English Textbook)

The example given is a short passage which is suitable to be attempted by the Malaysians Form 3 learners. Teachers can develop or adapt the passages with the appropriate length and level of difficulty which are suitable to cater the learners of different ages and level of proficiency. 
Finally, teaching the use of articles can be done by assessing learners' usage of articles in their writings. Teachers can always assess the learners' writings and highlight the articles used in them. Each articles used in the writing will be judged by the teachers on their appropriateness and accuracy. Every inaccurate articles used will be kept in records and emphasized to the learners in order to prevent the learners from committing the same errors in using the articles. According to Master (1995 in Celce-Murcia and Larsen-Freeman, 1999, p.292), this activity can help raise the learners' awareness in using the articles, be aware of the article errors that they often commit and improve the article usage of the learners.

\section{Conclusion}

The teaching and learning of the article usage has never been easy to both the teachers and learners of the English Language. Hence, strategies for teaching the articles $a$, an, and the are suggested to ease the teaching process of the articles in the classrooms, besides, helping the learners to achieve excellent mastery in the use of articles. These strategies are also outlined as a means to ensure that the teaching and learning process of the English grammar articles will be effective. 


\section{References}

Ahmad Salihin bin Mat Saat, Mohd Salleh bin Salehin and Wan Zuraidi bin Wan Zaid, (2003). English Form 3. Ee Ewe Hock (Editor). Sutrapadu (M) Sdn. Bhd.: Petaling Jaya.

Berry, R. (1991) Re-articulating the articles. English Language Teaching Journal, 45(3) 252-259. London: British Council.

Celce-Murcia, M. and Larsen-Freeman, D. (1999). The grammar book: an ESL/ EFL teacher's course. $2^{\text {nd }}$ ed. Boston: Heinle and Heinle.

Gan, C.W. (2001). The cloze test as an integrative measure of ESL proficiency (Master's thesis). Universiti Putra Malaysia, Selangor.

Grannis, O. (1972). The definite article conspiracy in English. Language Learning, 22(2), 275-289.

Lindstromberg, S. (1986). Guidelines for teaching the English article system. Cross Currents, 13 (1), 31-41.

Malaysia. Ministry of Education (2003). Curriculum Specifications for English Language Form 1. Kuala Lumpur: Curriculum Development Centre.

Malaysia. Ministry of Education (2003). Curriculum Specifications for English Language Form 2. Kuala Lumpur: Curriculum Development Centre.

Malaysia. Ministry of Education (2003). Curriculum Specifications for English Language Form 3. Kuala Lumpur: Curriculum Development Centre.

Malaysia. Ministry of Education (2003). Curriculum Specifications for English Language Form 4. Kuala Lumpur: Curriculum Development Centre.

Malaysia. Ministry of Education (2003). Curriculum Specifications for English Language Form 5. Kuala Lumpur: Curriculum Development Centre.

Master, P. (1990). Teaching the English articles as a binary system. TESOL Quarterly, 24(3), 461-478.

Master, P. (1997). The English article system: Acquisition, function, and pedagogy. System, 25,215-232.

McEldowney, P.L. (1977). A teaching grammar of the English article system. International Review of Applied Linguistics, 15(2), 95-112.

Richards, J. C. \& Rogers, T. S. (1986). Approaches and methods in language teaching: A description and analysis. Cambridge, UK: Cambridge University Press

Rinnert, C., \& Hansen, M. (1986, October). Teaching the English article system. Paper presented at the Japan Association of Language Teachers' International Conference on Language Teaching and Learning. Tokyo, Japan.

Selinker, L. (1972). Interlanguage. IRAL, 10(3), 209-31.

Skinner, B. F. (1974). About behaviorism. New York: Alfred A. Knopf.

Stubbs, J.B. \& Tucker, G.R. (1974). The cloze test as a measure of English Proficiency. Modern Journal, 58, 239-241.

Thornbury, S. (2004). How to teach grammar. Malaysia: Pearson Education Limited.

Whitman, R.L. (1974). Teaching the article in English. TESOL Quaterly 8(3), 253-262.

Yamada, J. \& Matsuura, N. (1982). The use of the English article among Japanese students. RELC Journal, $13(1), 50-63$. 